\title{
Small Business Capabilities for Employment
}

\author{
Salyakhov E. F. ${ }^{1}$, Zagidullina V. M. ${ }^{1}$, Fakhrutdinova A. V. ${ }^{1}$ \& Aleshina E. A. ${ }^{2}$ \\ ${ }^{1}$ Kazan Federal University, Institute of Management, Economics and Finance, Kazan, 420008, Russia \\ ${ }^{2}$ Kazan cooperative Institute, Kazan, 420045, Russia \\ Correspondence: Salyakhov E. F., Kazan Federal University, Institute of Management, Economics and Finance, \\ Kazan, 420008, Russia. Tel: 7-919-690-0666. E-mail: hulia_k@mail.ru
}

Received: March 19, 2015 Accepted: March 31, 2015 Online Published: April 30, 2015

doi:10.5539/ass.v11n11p341 URL: http://dx.doi.org/10.5539/ass.v11n11p341

\begin{abstract}
Small business is a significant sector of economy which influences on rates of economic growth, structure and quality of Gross Domestic Product of the country, promoting social and economic problem- solving search. Small enterprises are the most important reserve for social and economic development of the country, they quickly provide creation of new workplaces, form significant quantity of technological innovations, promote creation and maintenance at the necessary level of a middle class in society. As a current significant trend of development of small business in world economy acts that fact that many graduates try to find a job in a small business.
\end{abstract}

Keywords: small business, employment, economically active population, unemployment, middle class

\section{Introduction}

In modern economy of the developed countries small business flexibly and dynamically solves a number of social and economic problems. In particular it quickly provides creation of new workplaces, forms significant quantity of technological innovations, promotes creation and maintenance of a middle class in society at the necessary level.

\section{Theory}

According to canons of the economic theory, small business helps to form a competitiveness of an economical system, it influences on level of prices and employment.

Research of features of the Russian sector of small business regarding specifics of the solving employment problems is of interest from the point of workplaces stability and formation, features of demand for a labor supply, studying of a share and specific features of the creative human capital in small business, detection of the dependence on migrants work, etc.

Studying of the raised questions is interesting first of all from point of small business sector participation in regulation of processes of employment, in solving of an unemployment problem, in adaptation of economy to changes of market conditions and to calls of innovative economy (Moiseev \& Shurupova, 2010).

Addressing to the question of small business participation in formation of workplaces, a double role of small enterprises in this aspect should be noted. On the one hand small enterprises develop independent employment, form a point of the main workplaces, on the other hand, small business offers a wide range of non-standard forms of employment, in particular:

- A part-time and an overtime employment;

- A temporary employment regulated by the employment contract signed with the employee for a certain term;

- A casual employment, as possibility of a side-job (it is demanded in case of an insufficient labor income or low compensation on a primary place of employment);

- An employment on the basis of civil contracts and employment according to the scheme of leasing of the personnel;

- Secondary employment (an off-hour job);

- An informal employment (not regulated by contracts, not registered employment), etc. 
Possibility of various forms of combining part-time outside jobs development are for many small business enterprises is a chance to survive, and for all sector - is a way of flexible adaptation to changes of the market. Employment combinations can be viewed as "safety cushion" for the economy, which allows soften social consequences to changes in the demand of labor force on the market, and also adverse changes in the income on a primary place of employment (Bagautdinova, Gafurov, Kalenskaya, \& Novenkova, 2012).

\section{Results}

Figure 1 demonstrates dynamics of changes in amount of employees occupied in the Russian Federation economy in general and in the sector of small business in particular (including the microenterprises) from 2007 to 2013 .

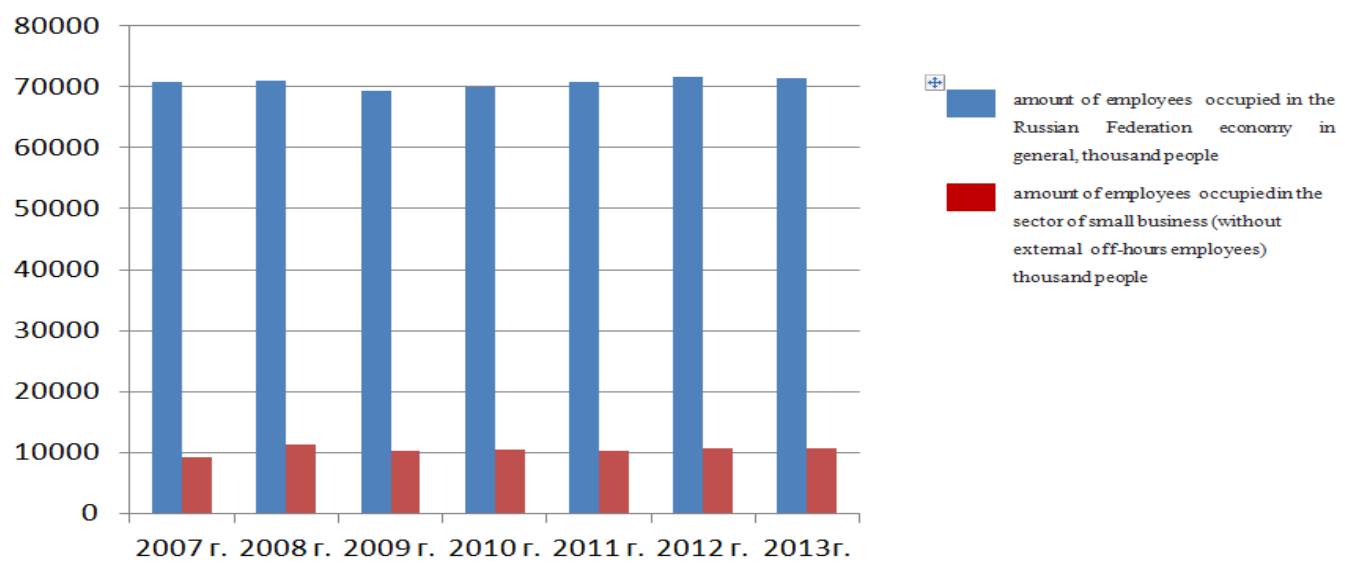

Figure 1. Share of employees occupied in the sector of small business in comparison with total employment in the Russian Federation economy from 2007 to 2013.

During the period of research the share of small business is stable. It remains on a mark - $14-16 \%$ of general employment. But if the total employment in 2013 reached and even over covered an indicator of 2008, in small business sector pre-crisis recovery of an employment rate hasn't reached yet (Labour and employment in Russia).

Data on Figure 2 shows the dynamics of changes in number of full time employees of small business enterprises and average amount of external off-hours employees in the Russian Federation economy from 2007 to 2013.

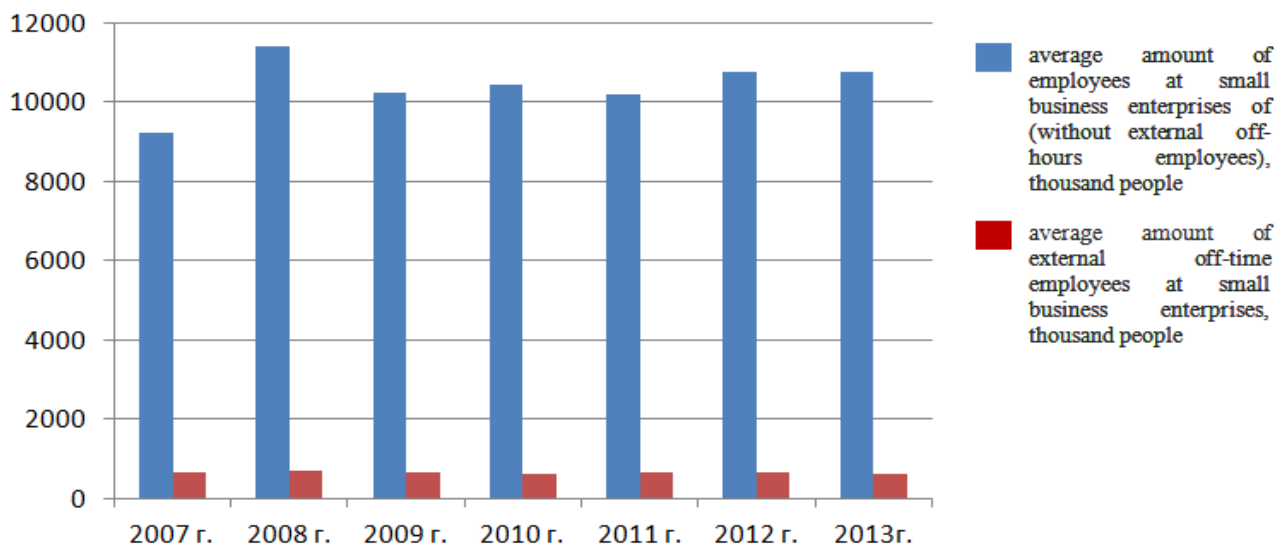

Figure 2. Number of full-time employees and a number of external part-time employees of small business enterprises in economy of the Russian Federation

It should be mentioned that in small entrepreneurship employment is mainly full-time, and part time external employees it is also characterized as stable for with an indicator on mark 5,6\%-7\% (Employment and Unemployment). 
In market economy measurement of external part-time jobs traditionally performed for the identification of dissatisfaction of individuals (a human capital) by the income and conditions on principal place of employment, inconsistence to their criteria of sufficient working place in terms of qualification and a safe work experience (Fakhrutdinova, 2009). According to The Russian Labor Code, off-hour job is determined as an accomplishment for a full-time job, at the free time, at a primary place of employment (the same employer, internal off-hour jobs) and (or) at another employer (external off-hour job). In most cases external off-hour jobs at small business enterprises is a work regulated by contract.

As a flexible ability for secondary employment, small business sector can be viewed as the mechanism of ensuring individual's self-realization (self-expression), adaptation to economics' instability, and in some cases even as a mechanism for surviving. Small business sector also helps to increase employees competitiveness in the conditions of an economic crisis, to develop some forms of social and labor mobility.

We also conducted an analysis of regional and industrial aspects through a prism employment in small business.
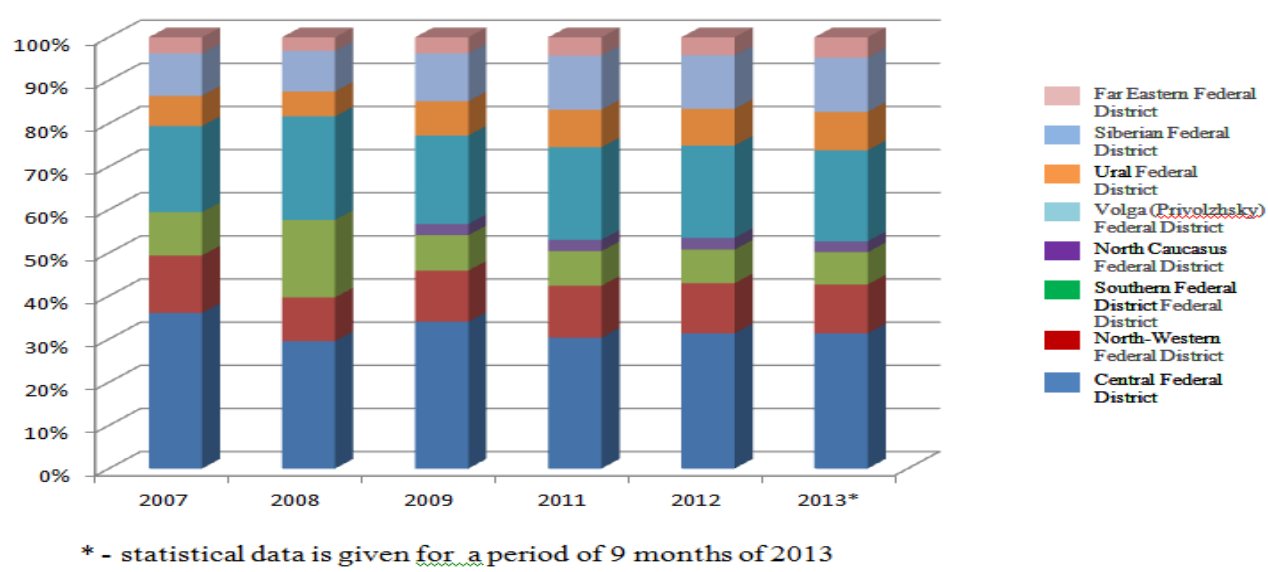

Figure 3. Distribution of average number of employees of small business enterprises (without external off-hour employees) on regions of the Russian Federation, per one thousand of people

In Figure 3 we provide data on regional distribution of employment of small businesses. Throughout the entire period of research by the leading results of employment in small business are presented in Central Federal District, on the second place with a gap by 1,5 times - are shown in the Volga (Privolzhski) Federal District, the third place beyond is in Siberian Federal District, it is followed by the Northwest Federal district with a small gap (Bagautdinova, Gafurov, Kalenskaya, \& Novenkova, 2012). As it was considered in the previous section, such situation in general keeps within an overall distribution of the population and economy of Russia.

As for specific amount of people occupied in small business on regions, here, according to data presented in Table 1, leadership distribution is different.

Table 1. Dynamics of percentage of people occupied in small business in relation to the total number occupied in economics of the region

\begin{tabular}{ccccccc}
\hline & 2007 & 2008 & 2009 & 2011 & 2012 & $2013^{*}$ \\
\hline Central Federal District Federal District & 16,22 & 17,4 & 16,9 & 15,13 & 16,02 & 15,8 \\
North-Western Federal District & 15,8 & 15,9 & 15,7 & 16,3 & 16,3 & 14,5 \\
Southern Federal District Federal District & 13,5 & 16,8 & 12 & 12 & 12 & 13,0 \\
North Caucasus Federal District & н.д. & н.д. & 6 & 6,2 & 6,4 & 9,8 \\
Volga (Privolzhsky) Federal District & 11,64 & 13,9 & 13,2 & 14 & 14,6 & 14,1 \\
Ural Federal District & 10 & 10,7 & 12,5 & 13,8 & 14 & 12,8 \\
Siberian Federal District & 9 & 11,3 & 11,4 & 13 & 13,5 & 13,3 \\
Far Eastern Federal District & 10 & 10,9 & 11 & 12,8 & 13,2 & 13,8 \\
\hline
\end{tabular}

* - statistical data is given for a period of 9 months of 2013 
Following the results of three quarters of 2013 the greatest share of people occupied at small enterprises $-15,8 \%$ is noted on the territory of Central Federal District, it is follow by North-West and the Volga Federal Districts. The highest rates of employment growth in small business were demonstrated in Far East and Siberian Federal Districts where the indicator grew from $10 \%$ to $13,8 \%$ and from $9 \%$ to $13,3 \%$ respectively.

In general the gap between the leading region and the region with the smallest present of people occupied in small business differs in nearly 2,5 times.

Interesting results were derived from the analysis of the quality characteristics of labor force occupied in small business. In this direction it is reasonable to consider qualification and educational characteristics of employment in small business (Safiullin, Bagautdinova, Safiullin, \& Gafurov, 2012).

The fact that many graduates want to find a job in small business sphere can be viewed as current significant trend of development of small business (Fakhrutdinova, Karasik, Safina, \& Miropol'skaya, 2013). The American scientists-economists in this respect formulated some reasons for which people prefer to employ to small business enterprises:

- In small companies the probability of staff rotation is higher;

- Speed of decision making and communicative processes is high;

- The personnel becomes closer to a source of the power in business:

- In small organizations possibilities of career development are higher;

- Small companies are less regulated by internal instructions and numerous rules.

As for the Russian institutional environment of small business, here is a bit different situation. Qualified personnel doesn't aim to work in small business sector because of impossibility to get high payments for work and/or benefits package which are available on large enterprises.

According to researches, $70 \%$ of young entrepreneurs consider that they have a lack of professional knowledge in the field of small business (Fakhrutdinova, Safina, Kolesnikova, \& Fedor, 2013). Many entrepreneurs suffer failure owing to absence of elementary knowledge and skills about the organization and business management. Also specialists connect the high level of failures in small business with absence of sufficient experience at many entrepreneurs, and understanding of problems which they can face in the future, entrepreneurs often have insufficient knowledge in the field of finance and accounting that leads to mistakes, this leads to impossibility to pay services of expensive management consultants or legal advisers, or services of the statistical information, that are necessary for effective business development.

According to survey conducted by the All-Russian center of public opinion study together with the all-Russian public organization of small and average entrepreneurship "Support of Russia", 50\% of entrepreneurs have to stop their business because of own incompetence in this sphere.

\section{Conclusions}

Considering industry concentration of small businesses in such spheres, as: the processing productions, construction, wholesale and retail trade; repair of trucking facilities, motorcycles, household products and subjects of private use, transport and communication, real estate transactions, lease and provision of services, it is necessary to mention entrepreneurs educational level.

All types of mentioned activities, except for real estate transactions, lease and provision of services can be defined by low indicators of people having higher education occupied in them. The greatest share is presented by employees, who have secondary professional, primary professional and secondary education (Kolesnikova \& 2012).

In general to characterize employment in small business in economy of the Russian Federation it is necessary to allocate a number of the features distinguishing it from other countries.

First, comparatively small number of people employed into small business sector. The level of employment in sector of small entrepreneurship the Russian Federation significantly lags behind countries like the USA, and countries of Europe. If in the Russian Federation not more than $25 \%$ of economically active population are in total are occupied in small and medium business, in other countries this indicator is 2-3 times higher.

Secondly, employment in small business in Russia is characterized by a high share of trade sphere. Similar indicators lay almost twice behind other developed countries of the world. At the same time the weakest focus of small entrepreneurship is in participation in innovative programs, scientific researches and developments. The 
percentage of the small businesses occupied in the field of science and innovations in the Russian Federation is 5 times lower, than indicators of developed countries.

Thirdly, disproportions in regional employment in small business are obvious. Small enterprises in Russia are not evenly distributed. The present of occupied in small business distinguishes up to 3 times.

Fourthly, employment in small business is usually accompanied by the worst organization and working conditions than on large enterprises where requirements and the rules of labor protection and safe engineering on workplaces are respected.

Fifthly, the educational and qualification structure of stuff occupied in small business is not as good as at big companies The greatest share is constituted of employees with secondary professional, primary professional and secondary education.

\section{References}

Bagautdinova, N. G., Gafurov, I. R., Kalenskaya, N. V., \& Novenkova, A. Z. (2012). The regional development strategy based on territorial marketing (the case of Russia). World Applied Sciences Journal, 18(Special Issue of Economics), 179-184.

Employment and Unemployment. Federal State Statistics Service. Retrieved from http://www.gks.ru/bgd/regl/b13_01/IssWWW.exe/Stg/d07/3-2.htm

Fakhrutdinova, E. V. (2009). Role of social sphere and social policy in the sustainable socio-economic development of the country. Economics, 8, 116.

Fakhrutdinova, E., Karasik, E., Safina, L., \& Miropol'skaya, N. (2013). The role of social protection in formation of quality of work life. World Applied Sciences Journal, 27(13), 77-81.

Fakhrutdinova, E., Safina, L., Kolesnikova, J., \& Fedor, M. (2013). Quality formation of working life of the youth. World Applied Sciences Journal, 27(13), 87-91.

Kolesnikova, J., \& Banket, S. (2012). Change in the level of life of the population depending on a period of social development. The Bulletin of Economics, Law and Sociology, 2, 12-14.

Labour and employment in Russia. Federal State Statistics Service. Retrieved from http://www.gks.ru/wps/wcm/connect/rosstat/rosstatsite/main/publishing/catalog/statisticCollections/doc_11 39916801766.

Moiseev, A., \& Shurupova, A. (2010). Creation of a new model of employment in a knowledge-based economy. $H R ., 14,63$.

Monitoring of the socio-economic development of Russia in the first half of 2013. Retrieved from http://www.economy.gov.ru/minec/activity/sections/macro/monitoring/doc20130724_01

Safiullin, L. N., Bagautdinova, N. G., Safiullin, N. Z., \& Gafurov, I. R. (2012). Influence of quality of the goods on satisfactions of consumers. International GSTF Business Review (GBR), 2(2), 225-232.

\section{Copyrights}

Copyright for this article is retained by the author(s), with first publication rights granted to the journal.

This is an open-access article distributed under the terms and conditions of the Creative Commons Attribution license (http://creativecommons.org/licenses/by/3.0/ 